\title{
The Exploration of an Appropriate Strategy of College English Instruction in China
}

\author{
Jiaolan Yan ${ }^{1} \&$ Guangwei Ding ${ }^{2}$ \\ ${ }^{1}$ Beijing Institute of Petro-chemical Technology, Beijing, 102617, China \\ ${ }^{2}$ Northern State University, USA \\ Correspondence: Dr. Guangwei Ding, Northern State University, Aberdeen, SD 57401, USA. E-mail: \\ guangwei.ding@northern.edu
}

Received: June 1, 2013 Accepted: June 19, 2013 Online Published: August 15, 2013

doi:10.5539/elt.v6n9p42 URL: http://dx.doi.org/10.5539/elt.v6n9p42

\begin{abstract}
College English (CE), a required course for college and university's students in China, plays a significant role in students' academic performance and future career success. The quality of College English instruction contributes to students' outcomes of English proficiency. Writing, as an important outcome of students' English learning, is an integral part to the assessment of College English competence. As an instructor paying less attention to students' English writing may have a dramatic consequence on reading instruction and thus has led to the inefficiency of improving students' overall English proficiency. Based on professor Yan's one year visiting scholar experience at University of Massachusetts (Boston) of the United States, especially by sitting in several English faculties' lectures, here the author tries to illustrate new ways of improving College English instruction at colleges and universities in China. It might have important impact on College English instruction pedagogies. The paper also attempts to provide suggestions for College English teachers to rethink their College English instruction pedagogies, especially in the area of College English Intensive Reading, in a changed, and changing, context.
\end{abstract}

Keywords: College English, instruction-based teaching, pedagogy-oriented teaching, critical reading, critical thinking

\section{Introduction}

With the social development and economy going global, English communicative competence has become increasingly demanding in many countries (Strauss, 1987; Zwagerman, 2008; Sin, 2009; Shi, 2010; Shi, 2011). English communicative competences for college graduates in China are becoming a requirement for almost any job (Li, 2012a and 2012b; Li and Casanave, 2012). The ability to use a fluent foreign language like English to communicate with the outside world becomes the essential indicator to test one's work competence (Liu, 2002; Flowerdew and Li, 2007; Harwood andPetric', 2012). Studies reported in The Globalization of English Report also show that "...92\% of global employees say English is required or important for their jobs .... 93\% (individual employees) say that English is required or important to get a promotion." (http://globalenglish.com/m/...globalenglish/globalization of English). Roger Howe, retired chairman and CEO of U.S. Precision Lens, said, "Nearly all the highly successful people I have observed over a long period, regardless of their professions, are clear and persuasive communicators in writing. It seems to be a common thread (Howe, 2007)."

The first publication of "College English Curriculum Requirements" (2005), also referred to as "Teaching Requirements" (2004 trial), greatly promoted college English teaching reform in China in many aspects and improved the quality of College English (CE) teaching and learning. Today both teachers and students attach great importance to improving students' English listening and speaking skills. However, English writing skills have been ignored to a certain degree.

$\mathrm{CE}$ instruction confronted many challenges in a changed, and changing, context. The result of a survey on 1,282 CE teachers in 289 colleges and universities in China showed that $42.8 \%$ students' English learning enthusiasm is not sufficient (Cai, 2010).In 2009, Dalian International IT Recruitment Assembly attracted more than 200 enterprises such as Dell, HP, Huawei Technologies Co., etc. More than 20,000 applicants applied for 5000 
opening positions. Unfortunately $60 \%$ candidates failed to be chosen by these enterprises because they did not have appropriate English reading and writing abilities (Lin, 2009).

The course of CE is implemented by CE Listening and Speaking Class (CELSC) and College English Intensive Reading Class (CEIRC), respectively, in colleges and universities in China. Writing Class is integrated into CEIRC. Although $\mathrm{CE}$ teaching and learning reform has recently received renewed interest, little work has focused on writing instruction, i.e., the effectiveness and efficiency of College English Intensive Reading Class (CEIRC) instruction has been less addressed.

Given the pressing nature of these problems and the recent developments in CE reform, we are convinced of the need to rethink our pedagogy from a new vantage point.

What is wrong with the current CE teaching and learning? What is the modern English as Second Language (ESL/FL) (Foreign Language) theory? Could CE teachers in China learn something from the United States' instructors? What are some of the strategies to assist college students to improve their English in China?

This study first examines the notion of instruction-based teaching vs. pedagogy-oriented teaching. Then the paper specifically evaluates two different types of lectures between Professor Jiaolan Yan and Professor Dorothy Nelson. Third, the paper presents the new emerging thoughts for Jiaolan Yan's transformative CEIRC's instruction. It also calls on CE teachers to rethink their CEIRC instruction pedagogies and theories in a changed, and changing, context (China).

\section{Conceptual Foundation: Instruction-Based Teaching vs. Pedagogy-Oriented Teaching}

\subsection{Instruction-Based Teaching}

According to Sowell (2005), instruction-based teaching is the imparting of knowledge or skill, in which curriculum is delivered to learners. Sowell stated that the instruction of the delivery of curriculum to students is through teaching agents (e.g., teachers, school staff, other learners, instructional materials, and programmed instruction). Passing preexisting contents on to learners is the essence of instruction-based teaching. Bruce and Weil (1972) defined instruction-based teaching as a teaching effort to lead the learner in a certain direction to achieve instructor/teacher planned goals and objectives. It is generally agreed that instruction-based instruction is not student-centered but teacher driven instruction.

The disadvantages of instruction-based teaching are obvious. Dewey (1902) discussed the problems of instruction-based instruction as follows:

"Problems of instruction are problems of procuring texts giving logical parts and sequences and of presenting these portions in class in a similar definite and graded way. Subject matter furnishes the end, and it determines method. ...Through instruction, the subject matter does not appeal [to the learner/student]; it cannot appeal; it lacks origin and bearing in a growing experience."

\subsection{Pedagogy-Oriented Teaching}

Pedagogy denotes the principles and methods of instruction or the activities of educating or teaching learners. Freire (1971) sustained that in pedagogy-based teaching, teachers and learners ought to transgress one another's boundaries: teachers becomes learners and learners become teachers in a shared and dialectical learning experience of overturning old structures and inventing new ones that are more democratic.

Hyun (2006a, 2006b, 2011) defined what pedagogy-oriented teaching does as following:

As an act of teaching, consciously promoting students' individualized meaning-making of facts/information, in which they are learning.

Pedagogy promotes the transformation of subject matter-driven instruction into the learner's self-producing meaningful facts, information, and knowledge.

In the process of individualized meaning-making in a meaningful learning, students tend to engage in a real-life based transdisplinary connections. 


\section{Comparative Analysis on Two Different Types of Teaching between Professor Jiaolan Yan and Professor Dorothy Nelson and Discussion}

Table 1. Two different types of teaching methodology (College English Curriculum Requirements, 2005; www.umb.edu/cla/english/dorothy_nelson/525/)

\begin{tabular}{|c|c|c|}
\hline & Jiaolan Yan's College English (CE) & Dorothy Nelson's English 101 \\
\hline $\begin{array}{l}\text { Course } \\
\text { description }\end{array}$ & $\begin{array}{l}\text { CE is a compulsory course for undergraduate } \\
\text { non-English major freshman and sophomore. The } \\
\text { objective of CE is to develop college students' } \\
\text { comprehensive English language competence in } \\
\text { using English so that they are able to communicate } \\
\text { efficiently both in oral or written discourse in their } \\
\text { careers and social activities. Meanwhile, they will } \\
\text { be able to enhance their ability to study } \\
\text { independently and improve their cultural quality } \\
\text { so as to meet the needs of China's social } \\
\text { development and international exchanges. In this } \\
\text { course, students will develop their listening, } \\
\text { speaking, reading, and writing strategies. CEIRC } \\
\text { is fundamental to CELSC. It focuses on } \\
\text { developing students' reading and writing skills. }\end{array}$ & $\begin{array}{l}\text { English } 101 \text { is an introductory course in critical } \\
\text { reading and writing that prepares students for } \\
\text { working with the complex texts and ideas they will } \\
\text { find in their college studies. English } 101 \text { teaches } \\
\text { students to discover and shape their own } \\
\text { perspectives in dialogue with challenging readings. } \\
\text { Through carefully sequenced assignments, } \\
\text { students are guided through various processes for } \\
\text { constructing academic essays that may include } \\
\text { journal writing, glossing texts, discussing student } \\
\text { papers in class, peer reviewing, and especially } \\
\text { revising. Readings and materials vary from section } \\
\text { to section. Note: English } 101 \text { satisfies the first half } \\
\text { of the college freshman writing requirements. }\end{array}$ \\
\hline $\begin{array}{l}\text { Teaching } \\
\text { philosophy }\end{array}$ & $\begin{array}{l}\text { In the past, the classroom was mostly } \\
\text { teachers-dominated. Instructors treated students as } \\
\text { a receptacle into which knowledge could be } \\
\text { "poured"; regard English as a collection of rules } \\
\text { and regulations that must be taught in the strictest } \\
\text { sense. Classroom offered chances to appreciate } \\
\text { models and practice. More or less instructors } \\
\text { regarded English not as another language to use, } \\
\text { rather than just a second language to learn. } \\
\text { Currently instructors are making efforts to conduct } \\
\text { a transformative students-centered instruction. } \\
\text { Teachers should offer an intellectually } \\
\text { challenging, stimulating, supportive, and caring } \\
\text { environment to learn in. }\end{array}$ & $\begin{array}{l}\text { Professor Dorothy Nelson stresses the importance } \\
\text { of learner-centered, not teacher-centered } \\
\text { experience. She believes that students have the } \\
\text { ability to learn to read well, to make meaning and } \\
\text { write good compositions in dialog with other } \\
\text { writers, with their classmates, with their teacher, } \\
\text { with the outside world they are experiencing and } \\
\text { with their inner experiences. She explains that } \\
\text { learning is experienced both on the page and in } \\
\text { action. The classroom should be a lively place, to } \\
\text { stimulate wonder, reflection, and imagination and } \\
\text { offer chances to appreciate experiences and } \\
\text { awakenings. She regards cultivating students' } \\
\text { critical reading, thinking, and writing as } \\
\text { fundamental to English } 101 \text {. }\end{array}$ \\
\hline $\begin{array}{l}\text { Teaching } \\
\text { methods }\end{array}$ & $\begin{array}{l}\text { Textbooks (College English Intensive Reading } \\
\text { I-IV; College English Listening and Speaking } \\
\text { I-IV; both are each semester a book with ten } \\
\text { units); task based; mainly individual work; rarely } \\
\text { pair work or group work. }\end{array}$ & $\begin{array}{l}\text { For Spring 2011, Professor Dorothy Nelson } \\
\text { assigned at least three books for students to read. } \\
\text { The Mind at Work by Mike Rose Penguin Books } \\
\text { paperback ISBN } 01430.3557 \text { (pbk.); Zeitoun by } \\
\text { Dave Eggers Vintage ISBN 978-0-307-38794-39 } \\
\text { (pbk.); Dwellings by Linda Hogan Norton ISBN } \\
\text { 0-393-03784-3. On the syllabus Professor Dorothy } \\
\text { Nelson mentioned that a few additional essays, } \\
\text { poems and/or short narratives may be included } \\
\text { during the term, group discussion; presentation; } \\
\text { peer reviewing, and especially revising; } \\
\text { conference time with individual students. }\end{array}$ \\
\hline Assignments & $\begin{array}{l}\text { Homework (exercises after each unit) and online } \\
\text { assignment (self-study materials in accordance } \\
\text { with each unit) }\end{array}$ & $\begin{array}{l}\text { For each class, she asked students to read some } \\
\text { parts of the three books or additional materials and } \\
\text { quote the part that interests them on the left side } \\
\text { and then write down their insights, their thoughts, } \\
\text { and their ideas on it on the right side of a }\end{array}$ \\
\hline
\end{tabular}




\begin{tabular}{|c|c|c|}
\hline & & $\begin{array}{l}\text { double-entry notebook. For the midterm or final, } \\
\text { coupled with very clear instructions for } \\
\text { requirements, students were asked to write essays } \\
\text { based on their former quotations and reflections in } \\
\text { the double-entry notebook. Drafts were required } \\
\text { for the mid-term paper and the final paper. Five } \\
\text { pages of double entry notes that were helpful to } \\
\text { students should be attached to the mid-term and } \\
\text { the final paper. }\end{array}$ \\
\hline Assessment & $\begin{array}{l}\text { Formative assessment is adopted. Students have } \\
\text { two quizzes, a mid-term examination and a final } \\
\text { examination. } \\
\text { Students' attendance, participation, assignment, } \\
\text { and their contribution to the class also count. } \\
\text { The percentages for the grading are as follows: } \\
\text { Final examination: } 60 \% \\
\text { Mid-term examination: } 10 \% \\
\text { On-line study: } \\
\text { Two quizzes: } \\
\text { Others (attendance; participation; assignments, } \\
\text { etc.) } 10 \%\end{array}$ & $\begin{array}{l}\text { She adopted a holistic method for grading } \\
\text { students' papers. Survey writing in her } \\
\text { introductory class offered critical information } \\
\text { about her students' past experience and academic } \\
\text { performance. Students' final grades were based on } \\
\text { students' development, which was their progress } \\
\text { being made after the whole course. } \\
\text { The percentages for the grading were as follows: } \\
\text { First essay } \\
\text { Mid-term paper } \quad 35 \% \\
\text { Final paper } \\
\text { Double-Entry notes and other upgraded writing } \\
\text { assignments } 15 \%\end{array}$ \\
\hline $\begin{array}{l}\text { Self reflection } \\
\text { on the teaching }\end{array}$ & $\begin{array}{l}\text { Students rarely make preparation for their classes; } \\
\text { passively take part in presentation, group } \\
\text { discussion, peer work, etc. Students seldom get } \\
\text { benefit from peer work and team work. What is so } \\
\text { often found in English class students in China is } \\
\text { an entrenched unwillingness to think carefully, } \\
\text { creatively, and daringly about an issue. }\end{array}$ & $\begin{array}{l}\text { Students make good preparation for their classes, } \\
\text { actively take part in the presentation, group } \\
\text { discussion, and peer work, etc. High motivation of } \\
\text { students' learning. They turn out a new student } \\
\text { with critical thinking and a critical learner when } \\
\text { the class ends. }\end{array}$ \\
\hline
\end{tabular}

We know that there are many aspects devalued the comparison (such as both the students and instructors, even after class environment, etc. are quite different). Chinese students study English as a foreign language and they don't have English environment after class. English 101 students, although not all the students are born Native Americans, have passed the required English examination. The course is to help students to improve their critical reading and writing and prepare themselves for their subsequent challenging subjects. Nevertheless, from the above analysis, we can see that Professor Yan's College English teaching is more instruction-based and Professor Nelson's English 101 is more pedagogy- oriented.

The goal of this paper is to represent the author's CE instruction and the observation of Professor Dorothy Nelson's teaching English 101 in such a way that practical applications can be taken and hypothesized and brought into our own practice. We do not advocate that we should completely adopt Professor Dorothy Nelson's teaching philosophies and methods as our own, but we believe that in following through her ideas, we could reconstruct our own.

\subsection{Students-Centered Pedagogy and Learning}

As described above, Chinese classes are mainly teachers-dominated. Teachers are used to teaching the whole time rather than give students enough time to learn by themselves. Although this situation has changed a lot during recent years, most of the classrooms are not yet student-centered. Cui et al. (www.doc88.com/p-08772066850.html 2012-1-15) conducted a survey on 1036 sophomore students in Ji Lin University and found that over $50 \%$ sophomore students think that "poured in receptacle" teaching and learning models are still prevalence and should be completely changed.

Professor Dorothy Nelson believes that the writing allows students to create a discovery process that requires writers to actively mobilize the use of systems of thinking and language. Writers go through problem-solving, the idea of the content, structure, ideas, and other processes. 
At the beginning of English 101, Professor Dorothy Nelson asked the students to prepare a double-entry notebook. For every reading assignment, she asked students to quote the part that interests them on the left side and then write down their insights, thoughts, and ideas on the right side. She inspired students to relate what they read to their real lives, such as what they thought and what they knew. Students were also encouraged to question and recognize what was new and difficult for them to understand.

She carefully managed the class, creating an atmosphere in which students question and experience how to acquire information from life, peers and reading materials, etc. and to facilitate their writing. That is, she encouraged students to use what they're learning to advance them and benefit others. In her opinion, Professor's responsibility was to watch out and facilitate students' needs in time. Her comments were usually short but to the point and provoked students to think deeply. We think this is the crucial time when students begin to learn.

For individual or special guidance, Professor Dorothy Nelson arranges conference time with students by appointment.This way, she instills and inspires life-long learning and educates them in a way that will empower them to contribute positively to their own environment and everyone's society. Like Professor Dorothy Nelson, $\mathrm{CE}$ teachers in China should consider the classroom as a place to inspire curiosity, enable students to learn, even if English is a foreign language in China.

We know that for second language learners, anxiety is a great obstacle for students to acquire knowledge. In English 101 as well as other courses I visited, the instructor guides students to experience, pursue knowledge for the course; helps students practice in class for preparation of their mid-term or final paper. This way students will not be afraid of exams; they will feel that exams are only as proof of their learning. Students are encouraged to arrange conference with the Professor to discuss their problems and question about the course. If CE teachers in China make their students experience learning this way, students will benefit a lot from learning, and gradually students will regard English learning as a lot fun, rather than just some mechanical knowledge to memorize.

\subsection{An Effective Pedagogy-Oriented Instruction}

Professor Dorothy Nelson believes that each student is unique; they have the ability to read well and write good compositions. Her role is to inspire students to internalize what they have read.

In his essay, "How to Read a Page," Richards (scholar, critic, and teacher) (1991) proclaimed, "We do not learn linguistic points from tables and examples; we learn through using the language-not in exercises but in the pursuit of a meaning they are seeking for a specific not a general purpose. In other words, the desire to improve our reading, worthy though it is won't help us unless it operates through the work of puzzling out a passage because we care what it says. The persistency of effects-no matter how well we make them overlap-will not systematize themselves into experience (knowledge that returns as power) unless they are heated by an immediate sustaining interest."

Although instructions on reading skills and reading efficiency are essential for effective writing for ESL students, what is more important is that students should be taught how to read critically, thinking about what they read and understanding the connections between ideas.

\subsection{Course Design Related to Real Life}

Most schools and the culture of schooling often encourage students to consider texts primarily as repositories of factual information (Nelson, 1999; Liu, 2002; Li and Casanave, 2011; Li, 2012a and 2012b). However, in classroom practice, it is important for teachers to make an effort to correlate what students read or learn with their real life or intended professions. It is beneficial for teachers to make an effort to illustrate how the skills and knowledge students are gaining in class will help them after graduation (Oliver and Omari, 1998; Shi, 2004; Shi, 2010; Shi, 2011). It is believed that students will be interested in a course if they are encouraged to associate what they read or learn with real life and begin to find relationship between study and life (Reid, 1987; Richards, 1991; Lin, 2009).

When students experience these connections, they begin to appreciate English as another language to use, rather than just a second language to learn (Krashen, 1982; Sternglass, 1988; Johnson et al., 1991; Kroll, 1991; Starfield, 2002).

\subsection{Integration of Reading, Writing, and Thinking into a Language Class}

Professor Dorothy Nelson approaches her class by means of reading, writing, and thinking, which she regards as interrelated activities. Several studies have examined on integration of reading and writing into a language class (Spack, 1990; Slave, 1996; Zhang, 2003; Sin, 2009). Bereiter and Scardamalia (1987) and Sternglass (1988) all recognized that reading builds knowledge of various kinds to use in writing and that writing consolidates 
knowledge in a way that builds schemata to read with. Without readings in ESL writing classrooms, teachers tend to rely heavily on expressive writing assignments based on personal experience or previous knowledge (Horowitz, 1986a, 1986b; Spack, 1988; Flower, 1990; Flowerdew and Li, 2007). Although this form of writing is valuable, it is limited and not the type of writing typically required from ESL students in higher education (Horowitz, 1986a; Reid, 1987; Carson, 1992; Cho and Jonassen, 2002). Using reading as a major source of new knowledge facilitates students to develop the ability to select and integrate new knowledge with knowledge and information they already possess and with their analyses and reactions to that new knowledge and information. It is this ability to integrate or internalize new information in writing that undergirds the notions both of knowledge- transforming (Bereiter andScardamalia, 1987) and of critical literacy (Flower et al., 1990) and may in fact be what we actually mean when we speak of comprehension of a text.

The research literature in L2 emphasizes the importance of purpose in both writing and reading (Eskey, 1986; Kroll, 1991; Shi, 2004; Cai, 2010). The literature on reading has pointed out that readers read for different purposes and that those purposes affect what is attended to and with what intensity (Eskey, 1986). According to Carson and Leki (1993), they argued that in reading classes, in which students are not reading to write, students are not reading but merely practicing reading. They also pointed out that the unfortunate effect of teaching reading and writing in separate courses has had dramatic consequences on reading instruction, robbing reading of its natural purpose and ignoring its social dimensions (Flower et al., 1990; Harwood and Petric, 2012). They further went on to argue for an integration of reading and writing instruction to promote a more social and interactive view of reading and writing.

The benefits of integrating L2 reading and writing in the same classroom thus seem undeniable and, since reading and writing draw upon the same cognitive world (Kucer, 1985; Cooper, 1990; Carson, 1993; Cui et al., 2010) reciprocal. Reading in the composition classroom sustains writing. Writing, even beyond providing a purpose for reading, clearly also enhances reading. Anticipating in writing the content of a text, i.e., writing before reading (Spack, 1990), primes schemata and thereby facilitates reading a text. Interacting with the content of a text by annotating and engaging the text in dialogue brings home more clearly the reader's own understanding of the text. It is often through the pressure of new or opposing ideas that our own ideas may become clear to us, just as it is often by expressing the ideas of others in our own words (in effect, translating them), that these other or new ideas begin to have meaning. Writing is a way of reading better "because it requires the learner to reconstruct the structure and meaning of ideas expressed by another writer. To possess an idea that one is reading about requires competence in generating the idea, competence in learning how to write the ideas of another." (Sternglass, 1988; Stapleton, 2010) Furthermore, as a student engages a reading text by responding or reacting to it in writing, in effect communicating with the writer through text, the essentially social nature of literacy becomes unmistakable (Strauss, 1987; Whitman, 1988; Slavin, 1996).

An approach toward integrating reading and writing in a language class is the appropriate pedagogical transformation for CE in China, which will make students learning English more interesting and fun and, most importantly, more beneficial.

\subsection{Group Discussion and/or Peer Comment}

It is believed that students learn best when they are actively involved in group work or peer work (Johnson and Johnson, 1989; Brandon and Hollingshead, 1999; Uribe et al., 2003). For English 101, Professor Dorothy Nelson allocated much of her class time for group discussion or peer work. She believes that group work in English writing class provides students with valuable opportunities to learn from each other; helps students to develop critical thinking and establishes confidence in their own writing. To encourage students to participate actively in the activities, in her syllabi (spring 2011), she wrote “...critical thinking is best developed in a class where differences of opinion and responses from your peers are encouraged and respected;... one learns not only about listening critically, but also about what it means to "lead" or advance the discussion; reading and commenting on each other's papers in class will provide valuable opportunities to imagine new possibilities for your own substantial revision."

Research frequently shows that there are clear educational advantages to be derived from collaborative learning (Slavin, 1996; Oliver and Omari, 1998; Brandon and Hollingshead, 1999; Carr, 2001). Many researchers such as Cooper (1990), Johnson and Johnson, (1989), Johnson et al. (1991), Whitman (1988), etc. reported that, regardless of the subject matter, students working in small groups tend to learn more of what is taught and retain it longer than when the same content is presented in other instructional formats. Students who work in collaborative groups also appear more satisfied with their classes. Furthermore, discussion assists students to share knowledge and accompanying interactions often lead to critical thinking (Cho, 2002; Saye\& Brush, 2002) 
and generating solutions (Uribe et al., 2003).

\section{Implementation and Suggestions for Other Colleagues}

A Chinese saying goes "Orange in the south is orange; in the north is deterioration of orange species". A similar understanding approach should be applied when teachers adapt Professor Dorothy Nelson's English 101 pedagogy into $\mathrm{CE}$ instruction. For example, we can adapt peer work or team work into our CE to help students to sharpen their ideas or understanding. However, due to different culture background, we have to make an effort to guide students how to play their role in the peer or team work and how to get the best out of it.

\subsection{Optional Transformative CE Curriculum and Teaching Pedagogy in China}

As mentioned before, CE is implemented by CEIRC and CELSC, respectively. There is no class time for writing. Both teachers and students pay little attention to writing. Teachers rarely ask students to write, perhaps only two or three times an academic semester. Furthermore, writing assignments are usually based on the topics of the intensive reading textbook. Most of the topics are outdated and not interesting to students. Consequently, students do not pay attention to writing either. Students do the writing assignments for the assignment's sake. Rarely do they write meaningful composition and hardly do they have a second thought of revision.

To meet the challenges CE confronted, CE Curriculum in China is suggested to transform and make the role of writing clear, put writing in its right place. It's true that writing competence should go with reading. But how should it be combined? As discussed above, it's beneficial for CE curriculum to transform CEIRC into CE Reading and Writing Class (CERWC), in which intergrades reading and writing, giving both reading and writing a purpose, that of communicating real thoughts and experiences. It is agreed that pedagogy-oriented instruction leads to real students and teachers' relationship (Freire, 1971; Bruce and Weil, 1972; Kroll, 1991; Liu, 2002). However, the introduction of a new theory or philosophy takes time. CE teachers in China have to be trained on the theory and practice of integrating reading and writing in an ESL classroom. For example, if we wish to maximize the benefits derived from integrating reading and writing, we need to determine specifically which types of writing activities will lead to the greatest enhancement of reading comprehension and vice versa.

\subsection{Sufficient and Quality Reading Materials}

It is well known that to write well, writers must engage with ideas (Krashen, 1982; Stapleton, 2010). They must encounter interesting ideas and connect them to their own knowledge and experience. The more student writers are intrigued by ideas, the more time and efforts they will spend in writing about them. The more they read or are read to in English, the easier it will be for them to write (Krashen, 1982). Sufficient and quality reading materials should be offered or suggested to the students. Only by immersion in quality English material can students use the language in broader domains and write well.

For English 101, Professor Dorothy Nelson assigned at least three books for students to read. During the semester, she prepared some handouts (additional essays, poems and/or short narratives) for students to better understand the purpose of the class and make students' learning easier.

It is obvious that the current CEIR I-IV textbooks for college and university's students in China (one book a semester, ten units on a variety of topics that are thought to be of high interest to our students) is insufficient for students to have good command of English. Moreover, our CEIR I-IV textbooks are short texts because they conveniently fit into our class periods better than long texts, they take less time to read, and they are thought to be easier to read than longer texts. But short texts are, in fact, likely to be more difficult to read since students never read enough about the subject to build knowledge that would allow them to read with ease and pleasure (Sternglass, 1988). Furthermore, constant shifts in subject matter make it harder for students because the students gear up for a new subject with each reading selection. In our own opinion, short texts with shifted subject matter are hard for students to find sustained interest in their language learning. They are also difficult for students to develop critical reading, writing, and thinking.

This challenges CE teachers, educators, and publishers in China to come up with longer and meaningful textbooks and reading materials. Some textbook publishers in China are now trying to transform CEIR textbooks to CERW textbooks. However, the short texts and ten units are the same. Hopefully, they will bring some improvements on these texts.

\subsection{A Double-Entry Notebook}

There are multiple-benefits for students to use double-entry notebooks. The double-entry notebook helps students to see their thoughts as they are writing them not only to perceive what they know and wonder about, but to perceive that they know and have this capacity for making meaning. Their writing in the double-entry 
notebook will enable them to become conscious of these intrinsic powers of the mind. It also provides students with ideas for their peer work, team work, and presentation.

Teachers should be aware that students will demonstrate various capabilities when first working with the double-entry notebook. Those students who are willing to engage in this practice with enthusiasm and believe that it could be useful, will make progress sooner than others. Others will be able to benefit from this method as they continue to develop as students.

\subsection{Essay Assignment}

For foreign language learning, language examination may be essential. However, papers or essays facilitate students to acquire language effectively. It is well known that papers or essays formulate and develop ideas, identify problems, and raise questions that relate to the concepts presented in the reading material. Moreover, students asked to compose a formal response also teach them critical thinking skills, such as analysis, interpretation, inference, and synthesis of knowledge.

For college and university students in China, they've already had a sufficient, even not good enough, mastery of English language. According to Zhang (2003) "During high school, given qualified English teachers, reasonable teaching arrangement, appropriate teaching methods, and students' hard work, students will have a good master of general English. As such students enter college or university they are capable of learning English for Special Purposes or Academic English."

For a transformative CE curriculum, colleges and universities in China may adopt paper or essay assignment for $\mathrm{CE}$ course assessment instead of assessment for examination purpose (mainly mechanical knowledge) only.

\subsection{Adaptation of Group Discussion, Peer Review and Peer Comment}

Due to the large class size (45 students on average), CE teachers in China, work hard to give feedback to every student on their writing assignment. However, the corrective feedback is very limited. On one hand, it takes a long period before the feedbacks come back to the students; that is, students cannot get timely feedback. On the other hand, most of the feedback focuses on the corrections of grammar mistakes and organization structure. Although these corrections help students to discover their weaknesses and address the problems, students get little idea of how to express his or her ideas or thoughts in an effective way. Furthermore, students pay little attention to teachers' corrective feedback. Few students give a second thought about teachers' correction or think of improvement for their future writing.

Adopting peer review and peer comments are good approaches to students' improvement of their writing by learning from each other. It can also reduce the workload of the teachers in the case of large class size. Teachers are also challenged to come up with effective ways to guide students how to do peer review and peer comments.

When we adopt group discussion, group work or peer work in CEIRWC in China, there are a lot of general strategies for us to take into account. First, students in China are not used to it; some students may think they should study only from the authorities and the Professor. They will be reluctant to follow the teachers' instruction. Teachers have to make an effort to explain to them and make them experience the benefits of group work or peer work, because this is the way to help students to learn from each other and to think critically and creatively. Second, teachers have to carefully explain to the class how the groups will work and how the group work will be graded. Last but not least, teachers have to give students the skills they need to succeed in groups.

\subsection{Learning as the Transformation of Individual Thinking}

Thanks to Professor Cadieux and Professor Dorothy Nelson, we found it beneficial and helpful both for students and for the teacher to begin a writing class by using survey writing. For the teacher, the survey is designed to know the students' prior experience of learning, students' expectations of the course, and students' plan after graduation, etc. For the students, survey writing situates students to think seriously about their purpose for the course, and maybe it induces students to make some preparation for the course.

We recommend it as an effective way for CE writing teachers in China. As China is a large country with diverse conditions, CE students are from different parts of China and from different majors; their background and English learning experience are quite different. As a result, their English proficiency varies significantly. It is always a good start for teachers to know something about the students before they give effective instructions. From here, the teachers will know where to start and how to start. Furthermore, it is agreed by educators that students' previous knowledge and life experience contribute to new leanings in the classroom. It is believed that students will strive academically when curriculum reflects and extends their concerns and interests. 


\section{Conclusion}

Good teaching theory and practice can only be proved in real teaching practice. However, it opens doors to the improvement of our past teaching experience. $\mathrm{CE}$ teaching and learning in China is at a time to change in a changed and changing context. In the course of adopting Professor Dorothy Nelson's teaching philosophy, pedagogy and practice into our own teaching practice, teachers have to continuously strive to provide that instruction which best meets the real needs and abilities of individual students. Anyway we should make an effort to offer our students the experience of communicating thoughts and experiences in English, appreciating English as another language to use, rather than just a foreign language to learn.

\section{Acknowledgements}

Professor Jiaolan Yan would like to thank Professor Eunsook Hyun, Professor Dorothy Nelson, and Professor Jessica Murray for their thorough readings of and valuable comments on earlier versions of the article. We would also appreciate Professor Dorothy Nelson's dedication in providing information incorporated into this manuscript.

\section{References}

Bereiter, C., \& Scardamalia, M. (1987). The psychology of written composition. Hillsdale, NJ: Erlbaum.

Brandon, D., \& Hollingshead, A. B. (1999). Collaborative learning and computer-supported groups. Communication Education, 48(2), 109-126.

Bruce, J., \& Weil, M. (1972). Models of teaching. Englewood Cliffs, NJ: Prentice Hall.

Cai, J. G. (2010). Ponder on reposition of college English teaching and learning. Foreign Language Teaching and Research, 4, 42.

Carr, C. S. (2001). Computer-supported collaborative argumentation: supporting problem-based learning in legal education. Paper presented at the CSCL.

Carson, J. G., \& Leki, I. (1993). Reading in the composition classroom: second language perspectives. Michigan University: Heinle \& Heinle.

Carson, J. G. (1992). Becoming biliterate: First language influences. Journal of Second Language Writing, 1, 53-76.

Cho, K. L., \& Jonassen, D. H. (2002). The effects of argumentation scaffolds on argumentation and problem solving. Educational Technology Research and Development, 50(3), 5-22.

College English Curriculum Requirements, also referred to as "Teaching Requirements" (2004 trial), Beijing Higher Education Press, 2005.

Cooper, J. (1990). Cooperative learning and college teaching: Tips from the trenches. Teaching Professor, 4(5), $1-2$.

Cui, et al. (2010). Retrieved January 31, 2012, from http://www.doc88.com/p-08772066850

Dewey, J. (1902). The child and the curriculum. Chicago: University of Chicago Press.

Eskey, D. E. (1986). Theoretical foundations. In F. Dubin, D. E. Eskey., \& W. Grabe. (Eds.), Teaching second language reading for academic purposes, 3-21. Reading, MA: Addison-Wesley.

Flower, L., Stein, V., Ackermn, J., Kantz, M. J., Mc. Cormick. K., \& Peck, W. C. (1990). Reading to write: Exploring a cognitive and social process. New York: Oxford University Press.

Flowerdew, J., \& Li, Y. (2007). Language re-use among Chinese apprentice scientists writing for publication. Applied Linguistics, 28, 440-465.

Freire, P. (1971). Pedagogy of the oppressed. Trans. Myra B. Ramos. New York: Seaview.

Harwood, N., \& Petric', B. (2012). Performance in the citing behavior of two student writers. Written Communication, 29(1), 55-103.

Horowitz, D. (1986a). Essay examination prompts and the teaching of academic writing. English for Special Purposes, 5, 107-120.

Horowitz, D. (1986b). Process, not product: Less than meets the eye. TESOL Quarterly, 20, 141-144.

Howe, R. (2007 Spring). "The importance of writing well”. Miamian Magazine, Miami University Alumni Association. 
Hyun, E. (2006a). Teachable moments: Re-conceptualizing curricula understandings (Studies in the Postmodern Theory of Education). New York: Peter Lang.

Hyun, E. (2006b). Transforming instruction into pedagogy in negotiation-oriented curriculum practice. Journal of Curriculum and Pedagogy, 3(1), 136-164.

Hyun, E. (2011). Transdisciplinary Higher Education Curriculum Transformation: A Complicatd Cultural Artifact. Research in Higher Education Journal, 11, 1-19.

Johnson, D. W., \& Johnson, R. T. (1989). Cooperation and competition theory and research. Education, MN: Interaction Book Company.

Johnson et al. (1991). Cooperative learning: increasing college faculty instructional productivity. Washington, D. C.: School of Education and Human Development, the George Washington University.

Krashen, S. D. (1982). Principles and Practice in Second Language Acquisition. Pergamon Press.

Kroll, B. (1991). Teaching writing in the ESL context. In M. Celce-Murcia (Ed.), Teaching English as a second or foreign language (2nd Ed.). New York: Newbury House.

Kucer, S. (1985). The making of meaning: Reading and writing as processes. Written Communication, 2 , 317-336.

Li, Y., \& Casanave, C. P. (2012). Two first-year students' strategies for writing from sources:Patchwriting or plagiarism? Journal of Second Language Writing, 21, 165-180.

Li, Y. (2012a). Text-based plagiarism in scientific writing: What Chinese supervisors think about copying and how to reduce it in students' writing. Science and Engineering Ethics. http://dx.doi.org/10 1007/s11948-011-9342-7.

Li, Y. (2012b). "I have no time to find out where the sentences came from; I just rebuild them": A biochemistry professor eliminating novices' textual borrowing. Journal of Second Language Writing, 21, 59-70.

Li, Y., \& Casanave, C. P. (2011). The footnote game: A student's strategic intertextual activities on an undergraduate linguistics assignment. Paper presented at the colloquium "students' use of sources in academic writing".

Lin, X. C. (2009). IT talents need to have a good command of English. Chinese Education Daily, 7-8.

Liu, R. Q. (2002). English curriculum transformation-from non-attached curriculum to unified curriculum standards. Foreign language teaching and research, 6, 34.

Nelson, L. M. (1999). Collaborative Problem Solving. In C. M. Reigeluth (Ed.), Instructional-Design Theories and Models. Laurence Erlbaum Associates, Inc., Publishers.

Oliver, R., \& Omari, A. (1998). Exploring student interaction in collaborative World Wide Web computer-based learning environments. Journal of Educational Multimedia and Hypermedia, 7(2/3), 263-287.

Reid, J. (1987). ESL Composition: The expectations of the academic audience. TESOL Newsletter, 21, 34.

Richards, I. A. (1991). Richards on Rhetoric. In A. E. Berthoff (Ed.). New York: Oxford.

Saye, J. R., \& Brush, T. M. (2002). Scaffolding critical reasoning about history and social issues in multimedia-supported learning environment. Educational Technology Research \& Development, 50(3), 77-96.

Shi, L. (2004). Textual borrowing in second-language writing. Written Communication, 21(2), 171-200.

Shi, L. (2010). Textual appropriation and citing behaviors of university undergraduates. Applied Linguistics, $31(1), 1-24$.

Shi, L. (2011). Common knowledge, learning, and citation practices in university writing. Research in the Teaching of English, 45(3), 308-334.

Sin, D. (2009). Non-locals lead way in campus research slots Quota opposed for HK students. South China Morning Post, May.

Slavin, R. E. (1996). Research on cooperative learning and achievement: What we know, what we need to know. Contemporary Educational Psychology, 21(1), 43-69.

Sowell, E. (2005). Curriculum: An integrative instruction. Upper Saddle River, NJ: Merrill Prentice Hall.

Spack, R. (1990). Guidelines: A cross- cultural reading/writing text. New York: St. Martin's. 
Spack, R. (1988). Initiating ESL students into the academic discourse community: How far should we go? TESOL Quarterly, 22, 29-51.

Stapleton, P. (2010). Writing in an electronic age: A case study of L2 composing processes. Journal of English for Academic Purposes, 9, 295-307.

Starfield, S. (2002). "I'm a second-language English speaker": Negotiating writer identity and authority in Sociology One. Journal of Language, Identity, and Education, 1(2), 121-140.

Sternglass, M. (1988). The presence of thought: Introspective accounts of reading and writing. Norwood, NJ: Ablex.

Strauss, A. (1987). Qualitative analysis for social scientists. Cambridge: Cambridge University Press.

The Globalization of English Report: Globalization Accelerates Need for Business English Communication Skills.Retrieved July 8, 2011, from http://globalenglish.com/m/...globalenglish/globalization_of_english

Uribe, D., Klein, J. D., \& Sullivan, H. (2003). The effect of computer-mediated collaborative learning on solving ill-defined problems. Educational Technology Research \& Development, 51(1), 5-19.

Whitman, N. A. (1988). Peer teaching: to teach is to learn twice. Washington, D.C.: ASHE. EICR Higher Education Report No. 4. Washington D. C.: Association for the Study of Higher Education. Retrieved from www.umb.edu/cla/english/dorothy_nelson/525/

Zhang, Z. B. (2003). Opinion on China's foreign language teaching reform. Journal of Foreign Languages, 4 , 126.

Zwagerman, S. (2008). The Scarlet P: Plagiarism, panopticism, and the rhetoric of academic integrity. College Composition and Communication, 59(4), 676-710.

\section{Copyrights}

Copyright for this article is retained by the author(s), with first publication rights granted to the journal.

This is an open-access article distributed under the terms and conditions of the Creative Commons Attribution license (http://creativecommons.org/licenses/by/3.0/). 